\title{
Independent Movement Experience with The Other Senses
}

Özlem Belir*

\begin{abstract}
According to Lynch (Lynch, 1960, 1997), who uses legibility as a reference to easily recognize and remember a space, the more the environment supports envisioning, the more legible it is.

It can be seen that the students who are studying design, have developed imagination with the sense of seeing. This illusion leads students to be concerned only with the effects of visual sense in the design process.

Selçuk University faculty of Architecture organized panel and workshops "Thinking with the Universal design" which included "direction finding" group study with students using smell, hearing and other senses except sight. At the "Architect Muzaffer" campus and its immediate surroundings, three different routes were set in the workshop and six students were asked to experience these routes using a blindfold. This study shows that when somebody looses their senses, they can use other senses more effectively. Students become aware of using other senses instead of using only sense of seeing. The secondary target of this workshop is to attract the attention of educators involved in design education.
\end{abstract}

Keywords: Independent movement, spatial legibility, multi-sensory, multiple perceptions, sensory maps

*Asst Prof. Dr. Faculty of Fine Arts and Architecture, İstanbul Gedik University, İstanbul, Turkey.

E-mail: ozlem.belir@gedik.edu.tr

Orcid ID: http://orcid.org/0000-0001-87147934 


\section{INTRODUCTION}

It is known that the creatures in the wild explore their environment, communicate and interact with each other by using sensory organs. Human beings also use the natural or built environments besides interacting and communicating. They shelter, attend school, go to hospital, engage in social activities and so on.

People need to perceive the environment they are in, so that they can use the environment they live in. They need to interpret the information they receives. The person who can use the environment and the environment, in which it is available, is unobstructed and therefore accessible.

Accessibility can be achieved by the perception of the physical consciousness of the person. Physical conditions such as seeing, hearing, touching, etc. are provided by our senses.

Perception in the concept of space has great importance in architectural education. Perception of space is often realized with our existing senses.

Broadly defined, human perception refers to what people come to know about objects, environments, and events without being told about them. This knowledge generally results from seeing, listening, touching, smelling, or feeling heat and air movement (Guth, Rieser, \& Ashmead, 2011).

Hearing, touching, seeing, smelling, and so on, are the pieces of perception.

\section{HUMAN - SPACE INTERACTIONS}

Human beings using built environment or buildings have various physical and mental features. Buildings that human beings live in, effects to feelings and interactions. In broad sense, disabled person is not only a human being with visually or motional impaired. As a matter of fact, disabled person is a human being with various sensory disorders who are ignored by the society. This person of the definition could be someone tired, pregnant, sad, mad, fat, short, tall, a lady with high heel shoes, a youth who is busy with a cell phone or could be slightly visually impaired, motional impaired.

Elder person with hearing loss and weak reflexes will be slower in reaction or will need more lights in the surroundings. They will need more handlers because of balance issues. If they live in nursing home they might be confusing their rooms because of 
obliviousness. We could come up with a lot more instances. Therefore if we could develop more senses into our architectural skills, and not see the physical differences as obstacles while shaping spaces and creating designs, we could create spaces where everyone could enjoy, be happy and be safe.

Human beings are in movement to explore their surroundings and also in the habit of learning what guiding their movements. When viewed from this angle, it could be said that, important and descriptive feature of perception is, it includes human research activity and environmental knowledge gained by seeing, listening, touching and moving. Researches about special perception show that human cognitive map develops with movement (Guth, Rieser, \& Ashmead, 2011).

Entire urban space could not be seen or experienced well enough from the point where human being stands. Human being needs the movement, collect the pieces in time and combines the collected data in mind. It is known that external factors help understanding the space as well as seeing.

According to Gibson (1966), some perceptual characteristics may vary due to the circumferential changes and the condition of the perceiver. Although other senses will remain the same (Guth, Rieser, \& Ashmead, 2011).

\section{SENSES}

According to Lynch (Lynch, 1960, 1997) a good environmental image gives its possessor an important sense of emotional security. He can establish a harmonious relationship between himself and the outside world. It is important to acquire the ability to interpret the senses received. The fact that the spaces are open to the senses facilitates the movement of the person. If it is necessary to briefly explain the senses except the sense of sight;

Sense of hearing: It is accepted that a person with visual impairment or visual insufficiency is affected by sound.

Vision and hearing are the senses best suited for perceiving things at a distance. For persons with visual impairments, hearing can provide an essential awareness of events beyond their immediate personal space. Many objects and environmental features can be identified and located through listening (Neuhoff, 2004).

Many persons who are accustomed to travelling without vision become skilful users of sounds from self-produced actions such as footsteps, cane contacts, and vocalizations. The focus here is not 
on what makes the sounds, but rather on how the sounds are affected by the environmental context. Because these actions are performed consistently, the person becomes familiar with how the sound is affected by environmental features. For example, properties of the walking surface just ahead are evident from how sharp or muffled cane taps sound. The size of a room can be perceived by listening to how much the sounds of one's footstep reverberate (Guth, Rieser, \& Ashmead, 2011).

It has been suggested that only visually impaired people have improved their ability to use sound to find directions. However, it has been proved by various researches that this is not the case. "The senses of the blinds do not show any superiority in respect of their senses according to non blind person. Their only supremacy is their experience of interpreting the stimuli they receive through these senses. " (Enç, Çağlar, \& Özsoy, 1985).

Sense of smell: The sense of smell has a certain importance during independent circulation. There are always a lot of smells in the surroundings that can tell exactly where a person who is not seeing is exactly. A pharmacy has a drug smell, a doctor's office has antiseptic smell and a restaurant smells like food (Özyürek, 1995).

Touch and haptic sensation: Touching is used to discover the properties of the immediate surroundings. In the formation and development of concepts related to the external world, the hand has great importance as the sense of touch and as a touching organ. It is very difficult to understand the true nature of an object without touching it, seeing it with eyes, hearing it with ear, and smelling is not sufficient. Our hands are our organs that will affect our mental activities. The hands are regarded as eyes of the blind and they are trained for this job.

With a long cane, pedestrians who are blind can extend their touching 1 to 2 meters beyond their arm's reach (or foot's reach). Long canes are powerful perceptual tools with which skilful users can, for example, perceive the material, slope, and elevation of the upcoming walking surface and the location and dimensions of the obstacles and openings along their paths (Guth, Rieser, \& Ashmead, 2011).

The perception is the haptic sensation, which allows you to reach the whole from piece by piece. In addition to touching, information comes from the sun and the wind. For example, in areas crowded with tall buildings, wind flow perpendicular to the line of travel is often a cue that a street is being approached or that an alley or some other break in a row of buildings is being passed. 
In open areas, the wind's direction can sometimes be used to identify one's general facing direction (Guth, Rieser, \& Ashmead, 2011).

Kinaesthetic sensation: besides objects with very small dimensions, size, distance, and proportion are perceived by the presence of the kinaesthetic (muscle) sensation, together with the feeling of touch. Muscle sensation or muscle memory, in fact, all the people use, but are unaware of, is recognized and gained importance in sight disabilities. Kinaesthetic sense is to be aware of an action or keep it in memory. The people who have visual impairments benefit from muscle memory to determine when to return, to climb stairs, or to measure distances (Özyürek, 1995).

The Portuguese architect Carlos Mourao, who lost his sight afterwards, in an interview during a visit to Turkey in 2010, says that, when the architectural structures became areas for multiple senses, he believed that the lives of the disabled would become even easier, and he showed the Suleymaniye Mosque as an example "Now they do not use courtyard in architectural structures, but courtyards are spaces where visually impaired people can perceive voices well without feeling uncomfortable... Suleymaniye is wonderful in this sense" used the expression. Mourao explains that historical places in Istanbul are made to appeal to many senses, "I enjoy being in historical places in Istanbul, the architecture is so extraordinary that I can perceive the space thanks to acoustics and smells" (Mourao, 2010).

In this sense, architecture involves many sensory experience areas that interact and fuse with each other rather than pure sight or classical five senses.

\section{ORIENTATION AND MOBILITY}

Orientation and mobility refers to the skills and techniques required for independent travel by persons who are blind or visually impaired. Orientation refers to the ability to establish and maintain an awareness of one's position in space, while mobility refers to the act of moving through space in a safe and efficient manner. When the two are integrated, the result is purposeful and directed movement. Both are dependent on accurate perception resulting from the successful interpretation of sensory clues into meaningful travel information (LaGrow, 2011).

If somebody feels safe therefore it is able to act independently. People can only "knowingly" provide their own security (Weisman, 1981). 
Berkeley (1973), Dixon (1968) and McKean (1972) report that anger, hostility and indignation resulted when users were faced with illegible public buildings (Weisman, 1981). According to Evans (1998), stress can occur when physical surroundings make the prediction of schema knowledge difficult (Başkaya, Wilson, \& Özcan, 2004).

Lynch uses legibility as a reference to easily understand and remember a space (Lynch 1997) Weisman defines legibility as the ease of the navigation (Weisman, 1981). Passini uses the term legibility in relation to navigation, as an environmental quality which easily opens up and offers comprehensible information (Passini, 1984). Legibility of a space is due to features of the place, depending on the markers they have and the scheme of the plan but the sensory clues of the person's features and space also affect the formation of the cognitive map in the mind of the person.

With this theoretical knowledge, thanks to the field experience whit the participation of the students, the aim was to change the perception that special solutions should be made for special people.

\section{METHODOLOGY}

Six students participated in the workshop. The profile of the students is given in the table below (Figure 1). There are variety of data because of the participant's different point of view due to their study at different universities and different departments.

Figure 1. Student participant profile

\begin{tabular}{|c|c|c|c|c|c|c|c|c|}
\hline \multirow{2}{*}{ \# } & \multicolumn{2}{|c|}{ Gender } & \multicolumn{2}{|c|}{ Campus and surrounding } & \multirow{2}{*}{ Department } & \multirow{2}{*}{ Degree } & \multirow{2}{*}{$\begin{array}{c}\text { use } \\
\text { Blindfold } \\
\end{array}$} & \multirow{2}{*}{$\begin{array}{c}\text { Experiment } \\
\text { Area }\end{array}$} \\
\hline & $\mathrm{F}$ & M & seen & not seen & & & & \\
\hline 1 & $x$ & & & $x$ & $\begin{array}{l}\text { Urban and Regional } \\
\text { planning }\end{array}$ & $\begin{array}{l}\text { post } \\
\text { graduate }\end{array}$ & $x$ & $\begin{array}{l}\text { Inside the } \\
\text { campus }\end{array}$ \\
\hline 2 & $x$ & & $x$ & & Architecture & $\begin{array}{l}\text { under } \\
\text { graduate }\end{array}$ & & $\begin{array}{l}\text { Inside the } \\
\text { campus }\end{array}$ \\
\hline 3 & $\mathrm{x}$ & & $x$ & & Architecture & $\begin{array}{l}\text { under } \\
\text { graduate }\end{array}$ & $x$ & Square \\
\hline 4 & $x$ & & $x$ & & $\begin{array}{l}\text { Urban and Regional } \\
\text { planning }\end{array}$ & $\begin{array}{l}\text { under } \\
\text { graduate }\end{array}$ & & Square \\
\hline 5 & $\mathrm{x}$ & & $\mathrm{x}$ & & Architecture & $\begin{array}{l}\text { under } \\
\text { graduate }\end{array}$ & & The streets \\
\hline 6 & & $x$ & $\mathrm{x}$ & & $\begin{array}{l}\text { Urban and Regional } \\
\text { planning }\end{array}$ & $\begin{array}{l}\text { under } \\
\text { graduate }\end{array}$ & $\mathrm{x}$ & The streets \\
\hline
\end{tabular}

Selçuk University Architect Muzaffer Campus and its surroundings were selected as the experiment area. Region is divided into three areas. (Figure 2)

1. Inside the campus. Total route: 400 meters

2. The streets around the campus (Şerafettin Street, Ankara Street, Görücü Street). Total route: 650 meters

3. Kültür Park Square near the campus. Total route: 635 meters 


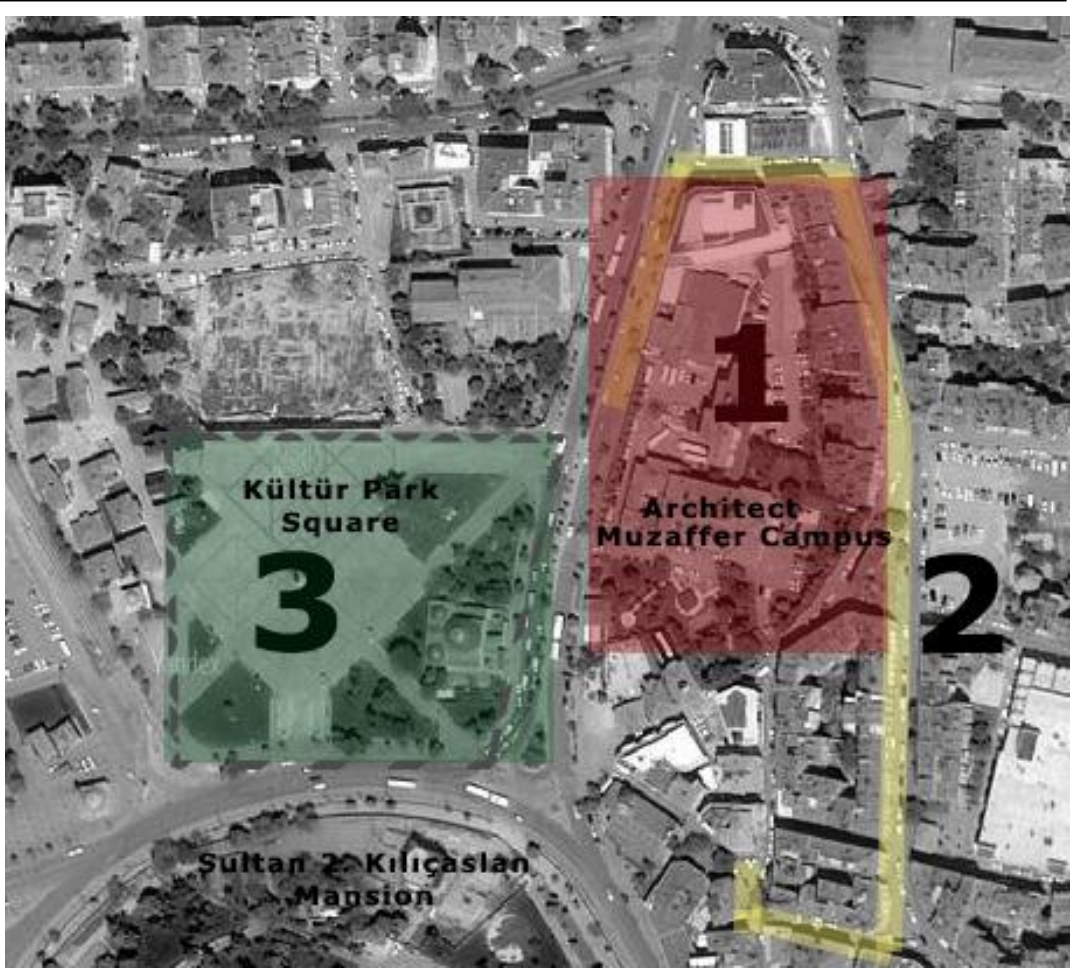

Figure 2. Area Map

Two students were selected for each study area and students from different disciplines were matched for each region. Students have been in their area for 2 hours and have experienced their routes. The study was conducted in May at a temperature of 23 degrees Celsius and from 10:30 to 12:30 hours.

One of the students in each area used eye bond and a white cane, the one who were not blindfolded has alerted his friend to the danger and recorded his findings about the environment. Students were briefed how to use the white cane before their experience.

It was requested from the blindfolded student that he/she should tell the student without the eye bond about what he/she hears, feels while following the route. It was also requested from the student without the eye bond, keep the intervention minimum with the blindfolded and ask frequently about their whereabouts.

At the end of the 2-hour, students should demonstrate their feelings about their routs on a field map and the students which are using blindfold were asked to write their feelings and senses. For this reason, they were asked 5 questions;

1. Did you feel the floor differences in your field?

2. Which building elements you have benefited from for orientation?

3. Do you feel smell in your area?

4. How are voices in your area and distance-related feelings?

5. Explain this experience in one word. 


\section{RESULTS}

The notes given by the students during their field experience are summarized in the table. (Figure 3)

\begin{tabular}{|c|c|c|c|}
\hline \multicolumn{4}{|c|}{ SENSORY } \\
\hline Smell & Sound & Tactile & Haptic \\
\hline diesel, gasoline odor & high vehicle & $\begin{array}{l}\text { material surface } \\
\text { difference }\end{array}$ & solar heat \\
\hline fruit, vegetable odor & bicycling & sand on the sidewalk & wind \\
\hline garbage smell & electric bicycle & supermarket trolley & shadow \\
\hline pastry & slowdown of vehicles & motorway & \\
\hline rose & wheelchair suitcase & $\begin{array}{l}\text { barriers on the } \\
\text { sidewalk }\end{array}$ & \\
\hline & footstep & hole & \\
\hline & bird & tree & \\
\hline & plane & soil & \\
\hline & water & electrical box & \\
\hline & television & paving stone & \\
\hline & cardboard box sound & & \\
\hline & door opening sound & & \\
\hline & children & & \\
\hline & crackle of dry leaves & & \\
\hline & car horn & & \\
\hline & dog & & \\
\hline & the sound of saw & & \\
\hline
\end{tabular}

In that study three students which are using eye bond responded to the 5 questions directed to them as follows:

Q 1 Did you feel the floor differences in your field?

The students working on the campus and in the square stated that they could not feel the floor differences and thus lost their direction (routes). High platforms without guardrails and grids on the ground have been obstacles to navigating and have caused them to be frightened.

Students travelling around the campus have noticed the difference between sidewalk, road, or pavement material. However, potholes on the pavement or on the road were dangerous for them. The raised grounds which are knee level are dangerous when they do not notice it with their white cane.

Q 2 Which building elements you have benefited from for orientation?

Students have benefited from pavement edges, water gutters or borders. However, students who experiment in the square are often confused their direction because of the monotonous coating. The fact that the square is always sunny is also the cause of the loss of direction.

Q 3 Did you feel smell in your area? 
The students have noticed the smells of trees, flowers and grass, on campus and in the square.

For students travelling around the campus, noticed the grocery store vegetables smell and noticed gasoline smell at the gas station at the start of the route.

Q 4 How voices in your area are affected the distance-related feelings?

The student on the campus was afraid of the noise of traffic and human crowds in the area due to the silence of his area and he did not know which direction to go. The student in the square felt disturbed when he heard dangerous noises (there was construction noise beside the area during the experiment) and felt the sound sources as it is closer than in fact.

Q 5 Explain this experience in one word.

Unconsciousness, indecision and ambiguity are the feelings of the 3 learners who use the eye bond.

Students using eye bond tried to protect themselves against possible hazards with a white cane. During these movements, they noticed parked vehicles, telephone or electrical boxes, sign boards, water channels on the ground. They often needed to touch the building elements, which they notice with white cane. At the same time they tend to drag their feet to feel the ground while walking. This could be caused due to the lack of texture variety in spaces.

The students easily perceived the natural effects such as the temperature, the shadow, because the work was done at noon on a day when the air temperature was 23 degrees. They notice the winds were cut or increased, and they tried to interpret this situation. They were able to perceive the movement of the sun and so predicted their direction.

Noises like sudden and persistent noise, such as high vehicle sound and horn sound, disturbed students with eye bond, this caused them not to feel safe. The sound of plane disturbed them and pressed other voices that they might receive data. This often caused them to lose their sense of direction.

All students have been quite successful in interpreting the voice they hear. They figured they were by the car wash because of the water sound, also noticed car loading because of the cardboard sound. 
Almost at the end of the workshop one student stated that the cars were turning left. When asked how he/she came up with that idea, he/she explains that the cars slow down and their noise becomes distant. This shows students success of interpretation after repetitive processes.

The texture change on the ground surface is another disturbing factor. Unidentified floor coverings without texture differences prevent students to understand their whereabouts in the space and created nondirectional feeling. The water gutters, which are continuous, have become a guiding element.

Smell became important and noticeable sense for the blindfolded students. When student, who experienced the space beforehand, smelled the fruits when passing by passed by the grocery store, predicted his/her whereabouts. Vegetables and fruits smells were something students never paid attention before. Grocery store became sensory landmark for the student who noticed the smell. The gas station located in the beginning of the route is also a sensory landmark for the blindfolded student.

Nondirectional, instability and uncertainty are results of students not being able to perceive the space. This is not caused by they are unable to see, but there are very little sensory landmarks in the space.

After the student experience, they have prepared the desired sensory map in digital environment and as a 3D model. They have classified the distinctive features outside of sight that they perceive during the experience, and they place the points on a map (Figure 4) In order to express the digital map to a person who does not see it, they have modelled the "sense map" they prepared with different materials and benefited from natural materials (Figure 5). 

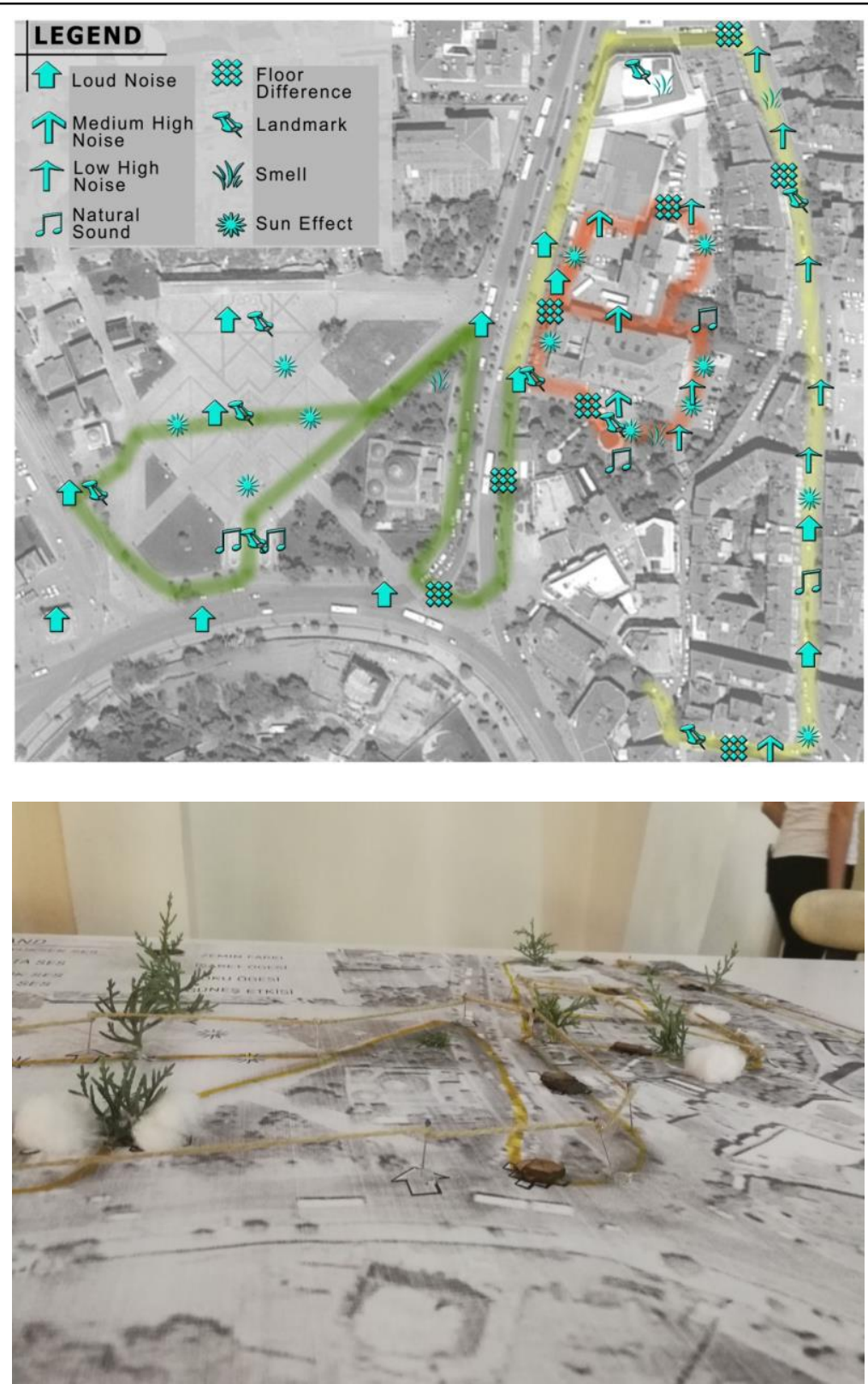

\section{CONCLUSION}

This piece of work has built and idea that design students must research solutions that affects all of human beings senses in their designs. They are now close to the idea of a design, that affects multiple senses, make spaces more legible.

Students became more aware of the senses they do not use frequently even though those senses exist.

Features that affects hearing, smelling, touching alongside with seeing creates liveable and accessible spaces.

Spatial legibility ensures proper navigation and successful movement, so it will be available for everyone.
Figure 4. Digital Sensory Map (above)

Figure 5. Sensory Map (below) 
This little work which is done with the blocking of the sight can be done with preventing the sense of hearing. The person with any sense of weakness will use the existing sense to bring down the most disadvantageous situation.

From the concept of universal design, the solutions that will create multisensory senses for the senses outside the visual in indoor and outdoor designs will not need to produce a "special solution" to some people.

\section{REFERENCES}

Başkaya, A., Wilson, C., \& Özcan, Y. (2004). Wayfindg in an Unfamiliar Environment: Different Spatial Settings of Two Polyclinics. Environment and Behavior , 36 (6), 839-867.

Enç, M., Çağlar, D., \& Özsoy, Y. (1985). Özel Eğitime Giriş. Ankara: Sevinç Matbaası.

Guth, D. A., Rieser, J. J., \& Ashmead, D. H. (2011). Perceiving to Move and Moving to Perceive: Control of Locomotion by Students with Vision Loss. (W. R. Wiener, R. L. Welsh, \& B. B. Blasch, Eds.) Foundation of Orientation and Mobility , I (1).

LaGrow, S. J. (2011). Improving Perception for Orientation and Mobility. Foundation of Orientation and Mobility , II (1).

Lynch, K. (1960, 1997). The Image of The City. Cambridge, London: The MIT Press.

Mourao, C. (2010, June 2). Osmanlı Mimarisine Hayranım. (S. Gazetesi, Interviewer)

Neuhoff, J. G. (2004). Ecological Psyhoacoustics: Introduction and History. Ecological Psychoacoustics .

Özyürek, M. (1995). Görme Yetersizliği Olan Çocuğu Bağımsızlı̆̆a Hazırlamak için Ana Baba Rehberi. Ankara: Başbakanlık Aile Araştırma Kurumu Yayınları.

Passini, R. (1984). Wayfinding in Architecture. New York.

Weisman, G. (1981). Evaluating architectural legibility: wayfinding in the built environment. Environment and Behavior , 13 (2).

\section{Resume}

Ozlem Belir (PhD 2013) has been working at Istanbul Gedik University, Faculty of Fine Arts and Architecture, Department of Architecture. She worked as a project manager in an architectural office in Istanbul between 1985-2013. Therefore her architectural experience is quite high. She is focused on Universal Design, accessibility, space perception and space design. 